\title{
長周期地震動による超高層住宅での室内被害評価 \\ - 屝や引出しの開閉を考慮した冷蔵庫の地震時挙動一 \\ EVALUATION OF INDOOR DAMAGE IN HIGH-RISE BUILDINGS \\ DUE TO LONG PERIOD GROUND MOTION
}

- Seismic behavior of refrigerator considering opening doors and drawers -

\author{
正月俊行*, 翠川三郎**, 三浦弘之***, 初岡徹朗**** \\ Toshiyuki MASATSUKI, Saburoh MIDORIKAWA, Hiroyuki MIURA \\ and Tetsuro HATSUOKA
}

\begin{abstract}
The aim of this study is to evaluate indoor damage in high-rise residential buildings due to long period ground motion. In this study the seismic behavior of a refrigerator was evaluated considering opening doors and drawers using shaking table tests and simulations. As the result of this study, the doors and drawers begins to open about $150 \mathrm{~cm} / \mathrm{s}^{2}$ in case that contents exist, and the refrigerator begins to move about $250 \mathrm{~cm} / \mathrm{s}^{2}$. And the refrigerator collides many times against walls severely with scattering contents during floor shaking. So it is highly possible that it blocks evacuation routes and injures people
\end{abstract}

Keywords : Seismic behavior of furniture, Refrigerator, High-rise building, Shaking table test, Rigid body dynamics, Long period ground motion 家具の地震時挙動, 冷蔵庫, 超高層建物, 振動台実験, 剛体の物理シミュレーション, 長周期地震動

\section{1. はじめに}

超高層建物では, 長周期地震動により継続時間の長い大振幅の摇 れが発生することが知られている。このような摇れでは, 家具等が 転倒するだけでなく大移動する可能性もあり, 地震時に建物が構造 的な損傷を受けない場合でも, 人的被害や避難に障害が生じる恐れ がある。榎田・ほか(2009)1 ${ }^{1}$ は, E-ディフェンスを用いて超高層建 物上階の室内が長周期地震動をうけてどのような状況になるのか振 動実験を行っており，実験対象にはオフィスのみならず，住宅を想 定した室内空間も含まれている。住宅の中でもキッチンでは, 家具 転倒対策がない場合, 食器棚や冷蔵庫が転倒し, 家具什器によって 受ける被害が命の危険に及ぶ可能性がある場所であることを指摘し ている。東北地方太平洋沖地震の際の東京都でのアンケート調査 ${ }^{2)}$ では, 家具類の転倒・落下・移動があった世帯の内, 食器棚および 冷蔵庫が転倒した世帯はそれぞれ $30 \%$ 程度および $10 \%$ 程度だった。

食器棚と比較すると冷蔵庫の転倒率は低いものの, 冷蔵庫は, 質 量が重く, 大きく滑って移動する可能性があり, 扉が摇れの最中に 開くと内容物が散乱したり，重心が前に移動して倒れやすくなった
りすることが指摘されている ${ }^{3)}$ 。そのため, 地震時の冷蔵庫の挙動 は複雑になるものと予想される。単純な直方体が仮定できる食器棚 のような家具に対しては, 床応答の等価振動数や入力レベルから家 具の転倒率や滑り量を評価する式が提案されており 4),5)，短周期の 摇れだけでなく，長周期の摇れについても被害事例と概ね整合する 結果が得られることが確認されている ${ }^{6)}$ 。しかしながら，複雑な挙 動をする冷蔵庫については, 例えば, 桜井ら 7)が冷蔵庫に対して振 動実験を行っているが，周期 0.5 秒以下の短周期の摇れに対する検 討であり, 周期が長く, 大変位の摇れとなる長周期地震動について の検討は見当たらない。

そこで, 本研究では, 長周期地震動による室内被害評価のための 基礎として, 振動実験と数值シミュレーションを用いて, 長周期地 震動に対する扉や開閉を考慮した冷蔵庫の複雑な地震時挙動につい て検討を行う。具体的には, まず, 振動実験の結果から摇れの大き さと挙動の関係について考察する。続いて, 剛体の物理シミュレー ションを用いて振動実験の再現を行って，実現象を再現できる計算 モデルを作成する。そして，その計算モデルに基づいて，条件を変

\footnotetext{
* (株構造計画研究所建築構造工学部

** 東京工業大学総合理工学研究科人間環境システム専攻 教授·工学(博士)

*** 広島大学大学院工学研究科建築学専攻 准教授. 博士 (工学)

**** 鹿島建設(侏)

(前 東京工業大学大学院 大学院生)
}

Structure Engineering Dept., Kozo Keikaku Engineering Inc.

Prof., Dept. of Built Environment, Tokyo Institute of Technology, Dr. Eng.

Assoc. Prof., Hiroshima Univ., Dr. Eng.

Kaiima Corporation

(Former Graduate Student, Tokyo Institute of Technology) 
えた数多くのケースに対して数值実験を行い, 扉や引出しの開閉や 内容物の量が, 冷蔵庫の地震時挙動に対してどのような影響を与え るか検討し, 長周期地震動によるキッチンでの室内被害を評価する。

\section{2. 振動実験}

\section{1 試験体諸元}

Fig.1 に振動実験に用いた冷蔵庫の写真と諸元を示す。幅 $80 \mathrm{~cm} \times$ 奥行 $65 \mathrm{~cm} \times$ 高さ $170 \mathrm{~cm}$ で, 総質量が約 $100 \mathrm{~kg}$ である。冷蔵庫上部 には両開きの扉があり, 下部には 3 段の引出しがある。冷蔵庫の底 面奥側は, 動かしやすいようにローラーとなっており, 手前側は, ローラーではない脚となっている。実験では, 床材にフローリング を使用した。摩擦係数については, 冷蔵庫本体下部を水平にゆっく りと引っ張り, 滑り出寸瞬間の力と滑り出した後の力から, それぞ れ静摩擦係数と動摩擦係数を求めた。その結果, 静摩擦係数は 0.30 , 動摩擦係数は 0.27 だった。

\section{2 振動実験概要}

冷蔵庫の振動実験として, 以下の 3 種類を実施した。

a) 本体の動きのみに着目して, 扉や引出しを開かないようにし て加振 (以後, 本体加振ケース(Doors and Drawers Fixed Shaking Case) と呼ぶ)

b）扉や引出しのみの開閉挙動に着目し，冷蔵庫本体を壁に固定 して加振 (以後, 扉・引出し加振ケース(Body Fixed Shaking Case) と呼ぶ)

c）冷蔵庫を壁に固定せず, 扉や引出しも固定しないで加振（以 後, フリー加振ケース(Free Shaking Case)と呼ぶ)

Fig.2 にそれぞれの実験の条件を示す。a)本体加振ケースでは, 冷蔵 庫本体の加振方向の移動量を变位センサーで，加速度を冷蔵庫下部 に取り付けた加速度センサーで計測した。内容物は配置していない。

b)扉・引出し加振ケースの実験は, 冷蔵庫本体を壁際に固定し, 片側の扉と上から 2 番目の引出しのみ開閉するようにして加振を行 った。扉や引出しに入れる内容物については, i)内容物無, ii)扉に $3 \mathrm{~kg}$ ・引出しに $3 \mathrm{~kg}$ の内容物配置, iii)扉に $7 \mathrm{~kg}$ ・引出しに $10 \mathrm{~kg}$ の 内容物配置, の 3 ケースを実施した。

c)フリー加振ケースの実験については, 各扉と引出しに, それぞ れ $3 \mathrm{~kg}$ ずつ内容物を配置し, 冷蔵庫上部の内部には 4 つの内容物 (各 $1 \mathrm{~kg}$ ）を配置した上で加振した（内容物の質量：計 $19 \mathrm{~kg}$ ）。予備実 験の結果, 加振により冷蔵庫が回転を伴って大移動し, センサーに よる計測が困難だった。そのため, 計測は実施していない。なお, 加振時の安全面を考慮して, バンドで泠蔵庫本体上部と壁を結び, 冷蔵庫が最大でも $50 \mathrm{~cm}$ 程度しか移動しないように拘束した。

加振は, 正弦波による 1 方向加振とし, 加振周期を $2 \sim 4$ 秒, 加 振加速度を $200 \sim 450 \mathrm{~cm} / \mathrm{s}^{2}$ とした。

\section{3 実験結果}

Fig.3 に実験結果を示す。横軸は加振周期, 縦軸は加振加速度で, 各加振ケースに対する冷蔵庫の挙動を示してある。a)本体加振ケー スについては, 移動量によりシンボルを分けて表示している。図を 見ると, 加速度 $250 \mathrm{~cm} / \mathrm{s}^{2}$ から滑りが始まり, 加振加速度が $300 \mathrm{~cm} / \mathrm{s}^{2}$ 以上になると，ほとんどのケースで移動量が $50 \mathrm{~cm}$ 以上となった。 $400 \mathrm{~cm} / \mathrm{s}^{2}$ 以上では $1 \mathrm{~m}$ 以上移動している。冷蔵庫は滑るのみで, 転 倒に至るケースは存在しなかった。

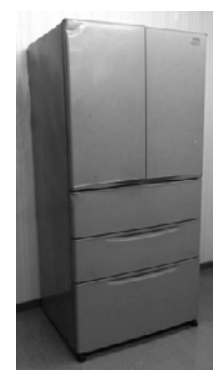

Size: W80 x D65 x H170 cm Weight: $102.6 \mathrm{~kg}$

Body : $76.6 \mathrm{~kg}$

Doors : $4 \mathrm{~kg} \times 2$

Drawers: $5 \mathrm{~kg} \times 2+8 \mathrm{~kg} \times 1$

Internal Volume: $480 \mathrm{~L}$

Static friction coefficient: 0.30

Dynamic friction coefficient: 0.27

Fig.1 Photo and specification of refrigerator

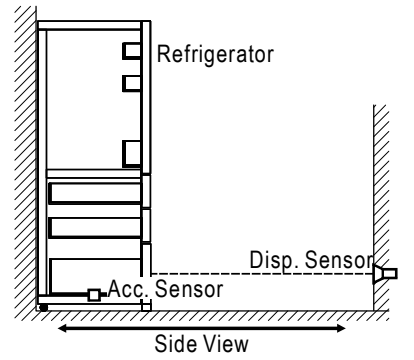

a) Doors and Drawers Fixed Shaking Case

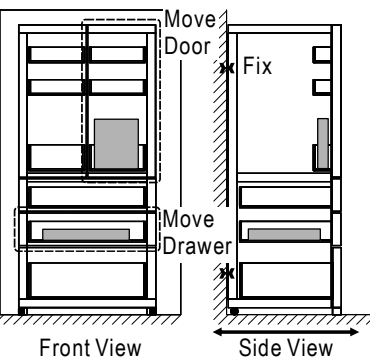

b) Body Fixed Shaking Case

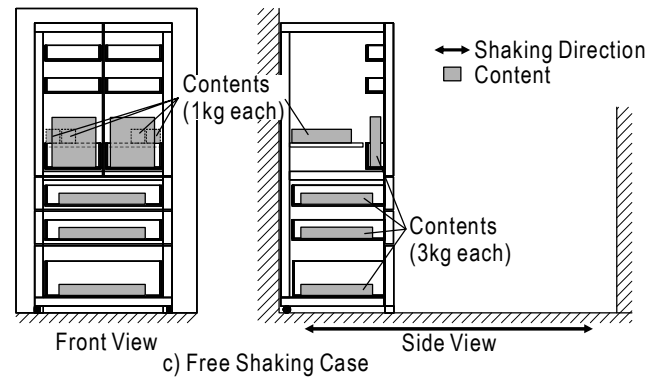

Fig.2 Conditions of shaking table test

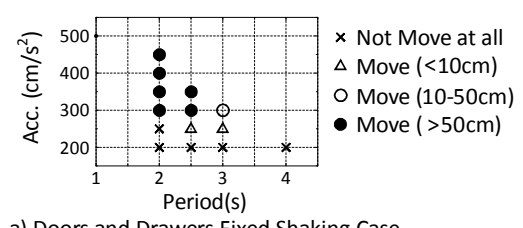

a) Doors and Drawers Fixed Shaking Case

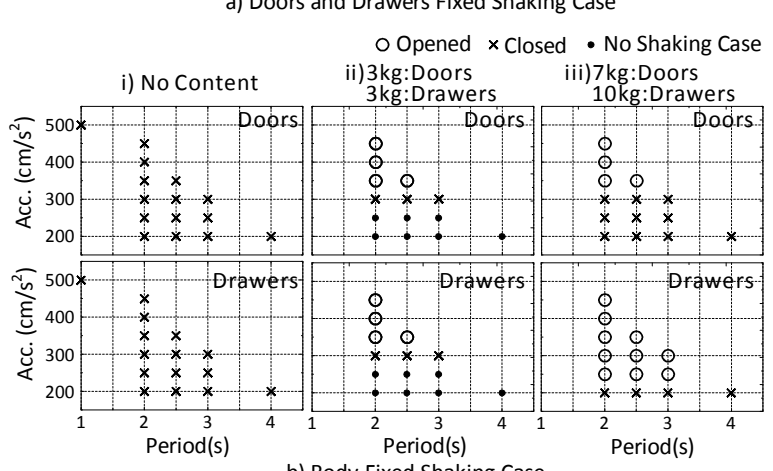

b) Body Fixed Shaking Case

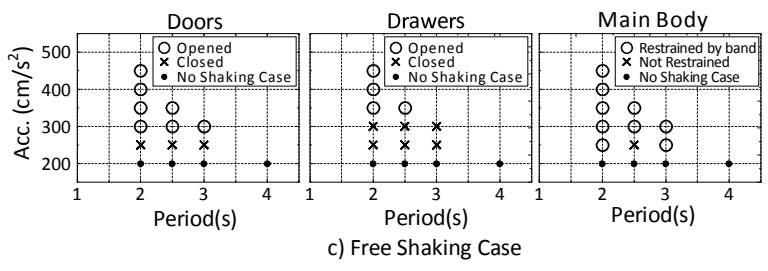

Fig.3 Results of shaking table test 
b)扉 • 引出し加振ケースについては, 扉 • 引き出しの開閉の有無 を表示している。図を見ると, 内容物の重さが重いほど, 扉や引出 しが開く加振加速度が小さくなる傾向が見られる。内容物がない場 合は, どの加振ケースでも扉や引出しが開くことはなく, 追加で周 期 1 秒, $500 \mathrm{~cm} / \mathrm{s}^{2}$ の加振も実施したが開かなかった。一方, 扉・引 出しに $3 \mathrm{~kg}$ の内容物が配置されている場合は, 屝も引出しも 350 $\mathrm{cm} / \mathrm{s}^{2}$ から開き始めた。扉に $7 \mathrm{~kg}$ ・引出しに $10 \mathrm{~kg}$ の内容物を入れた ケースでは，扉が $350 \mathrm{~cm} / \mathrm{s}^{2}$ ，引出しが $250 \mathrm{~cm} / \mathrm{s}^{2}$ から開いた。

c)フリー加振ケースでは, 扉・引出しの開閉の有無, および, 本 体が大きく移動してバンドにより移動量が拘束されたかどうかを示 している。扉は加振加速度 $300 \mathrm{~cm} / \mathrm{s}^{2}$ 以上, 引出しは $350 \mathrm{~cm} / \mathrm{s}^{2}$ 以 上で開いた。ただし, 扉・引出し加振ケースとは異なり, バンドに 引っ張られた衝撃がきっかけで扉や引出しが開く場合が多かった。 実験では冷蔵庫が転倒することはなかったが，バンドによる拘束が ない場合における転倒可能性は否定出来ない。

\section{3. シミュレーションによる振動実験の再現}

扉や引出しの開閉等が地震時における冷蔵庫の挙動に対して, ど のような影響を与えるのか検討するにあたり, まず, 冷蔵庫の現実 の挙動（振動実験結果）を再現できる計算モデルを構築する。シミ ュレーションのプログラムとしては, 剛体の物理運動シミュレーシ ヨンが可能な Springhead28)をベースとしたプログラムを用いる。 衝突する剛体間の接触力を求める方法はペナルティ法である。

\section{1 計算モデル}

Fig.4に作成した計算モデルを示す。底面奥側のローラーと扉は, 冷蔵庫本体と回転ジョイントで連結し, 平行移動する引出しはスラ イダジョイントで連結した。内容物については, 実験時の配置と同 じになるように内容物の形状を模擬した直方体を配置した（Fig.2 参照)。また， c)フリー加振ケースについては, シミュレーション でバンドの動きを再現するのは困難だったため, 冷蔵庫の正面から $50 \mathrm{~cm}$ の距離に壁を設けることで泠蔵庫の移動を制限し, バンドの 効果を疑似的に表現した。なお, 壁は冷蔵庫本体のみと衝突するよ うに設定し，扉や引出しの開閉を妨げないようにした。

Table1に, 冷蔵庫各部の質量と摩擦係数を示す。冷蔵庫本体の摩 擦係数は, 実測值を基本とし, 振動実験に合うように調整した。慣 性テンソルは, 質量や重心位置・立体形状から算出した。冷蔵庫本 体·扉・引出しの棚板等と内容物が接する際の摩擦係数については, 実測值が得られていないため, 既往の摩擦係数の測定結果 9)を参考 に, 静止摩擦係数 0.33 , 動摩擦係数 0.30 を設定した。

剛体が接触した際における接触力（垂直抗力・摩擦力）の計算時 に用いられるパラメータについて, バネ係数については, 冷蔵庫全 体の質量に対して垂直の理論固有周波数が $20 \mathrm{~Hz}$, 水平が $10 \mathrm{~Hz}$ と なるように設定した。ダンパ係数については, 垂直の跳㸚返り係数 が 0.3 程度になるように設定した ${ }^{10)}$

ローラーの回転ジョイントには, ジョイントの回転速度に比例し た回転抵抗をかけた。実物のローラーは, 冷蔵庫の重みにより若干 つぶれていたため, 動き始めの抵抗が大きいと推測された。その影 響をシミュレーションにも反映させるため, 回転速度がある閾值以 上になるまでは大きな回転抵抗を設定しておき, 閾值を超えたら回 転抵抗を下げるような非線形なバネを設定した。扉の回転ジョイン

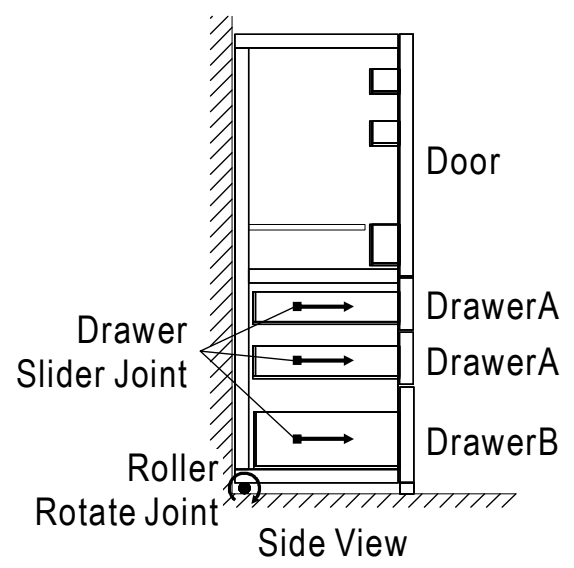

$100 \mathrm{~cm}$

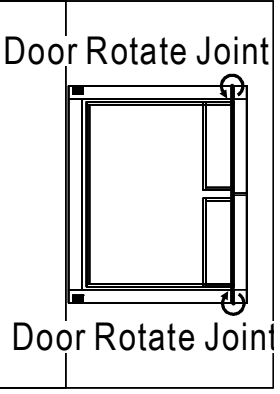

Plan View

Fig.4 Simulation model of refrigerator

Table1 Mass and friction coefficient of simulation model

\begin{tabular}{|c|l|c|c|c|c|}
\hline \multirow{2}{*}{ Parameters } & \multicolumn{4}{|c|}{ Refrigerator } \\
\cline { 2 - 6 } & Body & Door & DrawerA & DrawerB & Roller \\
\hline Mass(kg) & 76.6 & 4.0 & 5.0 & 8.0 & 0.2 \\
\hline Static Friction Coefficient & \multicolumn{5}{|c|}{0.30} \\
\hline Dynamic Friction Coefficient & \multicolumn{5}{|c|}{ Contents } \\
\hline \hline \multirow{3}{*}{ Parameters } & \multicolumn{5}{|c|}{ iii) 7kg in Doors, } \\
\cline { 2 - 5 } & ii) 3kg in Doors, & in Doors & in Drawers \\
\hline Mass(kg) & $3 \mathrm{~kg}$ in Drawers & 10.0 \\
\cline { 2 - 6 } & in Doors & in Drawers & in Drawers \\
\hline Static Friction Coefficient & 3.0 & 3.0 & 7.0 & 10.33 \\
\hline Dynamic Friction Coefficient & \multicolumn{4}{|c|}{0.30} \\
\hline
\end{tabular}

Table2 Joint parameters

\begin{tabular}{|c|c|c|c|c|}
\hline \multicolumn{2}{|c|}{ Joint Parameters } & $\begin{array}{c}\text { Roller } \\
\text { Rotate Joint }\end{array}$ & $\begin{array}{c}\text { Door } \\
\text { Rotate Joint }\end{array}$ & $\begin{array}{c}\text { Drawer } \\
\text { Slider Joint }\end{array}$ \\
\hline \multicolumn{2}{|c|}{ Control Type } & Rotation Vel. & Rotation Disp. & Translation Disp. \\
\hline \multirow{4}{*}{ Spring } & Threshold & $18 \mathrm{rad} / \mathrm{s}$ & $0.01 \mathrm{rad}$ & $0.01 \mathrm{~m}$ \\
\cline { 2 - 5 } & Initial Value & 0.1 & 650 & 3250 \\
& Joint Value<Threshold & $\mathrm{N} \cdot \mathrm{m} \cdot \mathrm{s} / \mathrm{rad}$ & $\mathrm{N} \cdot \mathrm{m} / \mathrm{rad}$ & $\mathrm{N} / \mathrm{m}$ \\
\cline { 2 - 6 } & Value during Reduction & 0.0001 & 5 & 30 \\
& Joint Value>=Threshold & $\mathrm{N} \cdot \mathrm{m} \cdot \mathrm{s} / \mathrm{rad}$ & $\mathrm{N} \cdot \mathrm{m} / \mathrm{rad}$ & $\mathrm{N} / \mathrm{m}$ \\
\hline
\end{tabular}

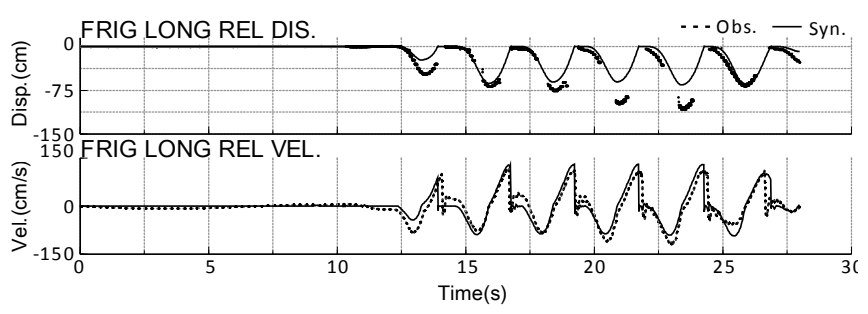

Fig.5 Simulation result of refrigerator for doors and drawers shaking case

(Period 2.5sec, Acceleration $350 \mathrm{~cm} / \mathrm{s}^{2}$ )

トには，回転角に比例した抵抗をかけるように設定し，引出しのス ライダジョイントには移動量に比例した抵抗を設定した。扉と引出 しは，開き始めの抵抗が大きく，ある程度開くと小さな抵抗で動く ようになる。そのため, 屝や引出しの開きが小さいときはジョイン 
トに大きな抵抗が発生するようにしておき，ある閾值まで開いたら 抵抗を下げるようにした。Table2 にジョイントに設定したパラメー タを示す。表中の Control Type に記載してあるジョイントの值（例 えば，ジョイントの回転速度）に，バネ係数(表中の Spring の值) をかけて抵抗力を計算している。バネ係数を変化させる閾値は, 表 中の Threshold に示してある。バネ係数や閾值の值は, 振動実験に 近い結果が得られるように試行錯誤により設定した。

\section{2 振動実験の再現結果}

Fig.5 に a)本体加振ケースの再現結果の一例を示す。図は, 加振 周期 2.5 秒 - 加速度 $350 \mathrm{~cm} / \mathrm{s}^{2}$ の正弦波加振時における冷蔵庫の床に 対する相対変位，相対速度を示している。実線がシミュレーション で破線が実験結果である。相対変位については，変位センサーが対 象物を捉えられず，異常值を示した時間のデータを表示していない ため, 空白の部分がある。相対速度は, 振動台と冷蔵庫に設置した 加速度センサーから得られた加速度時刻歴波形から求めた。図を見 ると, 動き出しのタイミングや相対変位・相対速度波形の全体的な トレンドは同じ傾向となっており，振動実験を概ね再現できている ものと考えられる。

Table3 にb)扉・引出し加振ケースにおける振動実験の再現結果一 覧を示す。表には，シミュレーションと振動実験における各加振ケ 一スに対する扉の開閉の有無が示してある。表を見ると, シミュレ ーションにより得られた扉や引出しが開き始める加振加速度は, 内 容物が多い iii)のケースでは, 振動実験と近い結果となっているこ とが分かる。内容物が少ない ii)のケースでは, シミュレーションと 振動実験が整合しないケースがいくつか見られるが，この一因とし ては，扉や引出しと本体間のゴム磁石の密着等を今回のモデルでは 表現出来ていないことが考えられる。

c)フリー加振ケースにおいては, Fig.6 に示すように本体が大きく 移動して，バンドによる引っ張りが生ずる場合があった。図には， 実験とシミュレーション両方の結果を示しており，シミュレーショ ンでも実験と同様に, バンドに引つ張られた衝撃で扉や引出しが開 いているのが分かる。シミュレーションによる振動実験の再現性の 確認は，扉や引出しの開閉の有無とバンドによる引っ張りの有無の 2 点に着目して行った。振動実験の再現結果の一覧を Table4 に示寸。 表を見ると, 前述の 2 点については, 概ね振動実験を再現出来てい るものと考えられる。

\section{4. 扉や引出しの開閉を考慮した冷蔵庫の地震時挙動 \\ 4. 1 検討方針}

ここからは，作成した計算モデルを用いて，振動実験で加振不可 能なケースも含めて，条件を変えた数多くのケースに対して数值実 験を実施し, 扉や引出しの開閉の有無や内容物の量が冷蔵庫の地震 時挙動に与える影響について検討を行った。

数值実験において現実的な条件設定をするための事前検討として, 約 70 棟の超高層集合住宅のキッチンの間取りを調査した。その結 果, 冷蔵庫の対面がシステムキッチンになっている Fig.7 のような 間取りが最も多く, 冷蔵庫の前後方向の最大移動可能距離は $1 \mathrm{~m}$ 前 後であった。そのため, 数值実験では, 冷蔵庫前方 $1 \mathrm{~m}$ の位置にシ ステムキッチンを想定した高さ $90 \mathrm{~cm}$ の壁を配置した。

本検討では, 冷蔵庫の地震時挙動に影響する因子として, (1)床応
Table3 Simulation result of body fixed case

:Open -: Not Open

\begin{tabular}{|c|c|c|c|c|c|}
\hline \multicolumn{6}{|c|}{ i) No Content } \\
\hline \multicolumn{2}{|c|}{ Shaking Case } & \multicolumn{2}{|c|}{$\begin{array}{c}\text { Shaking } \\
\text { Table Test }\end{array}$} & \multicolumn{2}{|c|}{ Simulation } \\
\hline \begin{tabular}{|c|} 
Acc. \\
$\left(\mathrm{cm} / \mathrm{s}^{2}\right)$
\end{tabular} & $\begin{array}{l}\text { Period } \\
\text { (s) }\end{array}$ & Door & Drawer & Door & Drawer \\
\hline 500 & 1.0 & - & - & - & - \\
\hline \multicolumn{6}{|c|}{ ii) $3 \mathrm{~kg}$ in Door and $3 \mathrm{~kg}$ in Drawer } \\
\hline \multicolumn{2}{|c|}{ Shaking Case } & \multicolumn{2}{|c|}{$\begin{array}{c}\text { Shaking } \\
\text { Table Test }\end{array}$} & \multicolumn{2}{|c|}{ Simulation } \\
\hline $\begin{array}{c}\text { Acc. } \\
\left(\mathrm{cm} / \mathrm{s}^{2}\right)\end{array}$ & $\begin{array}{l}\text { Period } \\
\text { (s) }\end{array}$ & Door & Drawer & Door & Drawer \\
\hline 300 & 2.0 & - & - & - & - \\
\hline 300 & 2.5 & - & - & - & - \\
\hline 300 & 3.0 & - & - & - & - \\
\hline 350 & 2.0 & 9 & 9 & - & - \\
\hline 350 & 2.5 & 0 & 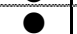 & - & - \\
\hline 400 & 2.0 & 0 & 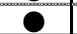 & - & 0 \\
\hline 450 & 2.0 & 0 & 0 & 0 & O \\
\hline
\end{tabular}

iii) $7 \mathrm{~kg}$ in Door and $10 \mathrm{~kg}$ in Drawer

\begin{tabular}{|c|c|c|c|c|c|}
\hline \multicolumn{2}{|c|}{ Shaking Case } & \multicolumn{2}{c|}{$\begin{array}{c}\text { Shaking } \\
\text { Table Test }\end{array}$} & \multicolumn{2}{l|}{ Simulation } \\
\hline $\begin{array}{c}\text { Acc. } \\
\left(\mathrm{cm} / \mathrm{s}^{2}\right)\end{array}$ & $\begin{array}{c}\text { Period } \\
(\mathrm{s})\end{array}$ & Door & Drawer & Door & Drawer \\
\hline 200 & 2.0 & - & - & - & - \\
\hline 200 & 2.5 & - & - & - & - \\
\hline 200 & 3.0 & - & - & - & - \\
\hline 200 & 4.0 & - & - & - & - \\
\hline 250 & 2.5 & - & 0 & - & 0 \\
\hline 250 & 3.0 & - & - & - & 0 \\
\hline 300 & 2.0 & - & - & - & 0 \\
\hline 300 & 3.0 & - & 0 & 0 & 0 \\
\hline 350 & 2.0 & - & - & - & 0 \\
\hline 350 & 2.5 & 0 & 0 & 0 & 0 \\
\hline 400 & 2.0 & 0 & 0 & 0 & 0 \\
\hline 450 & 2.0 & 0 & 0 & - & 0 \\
\hline
\end{tabular}
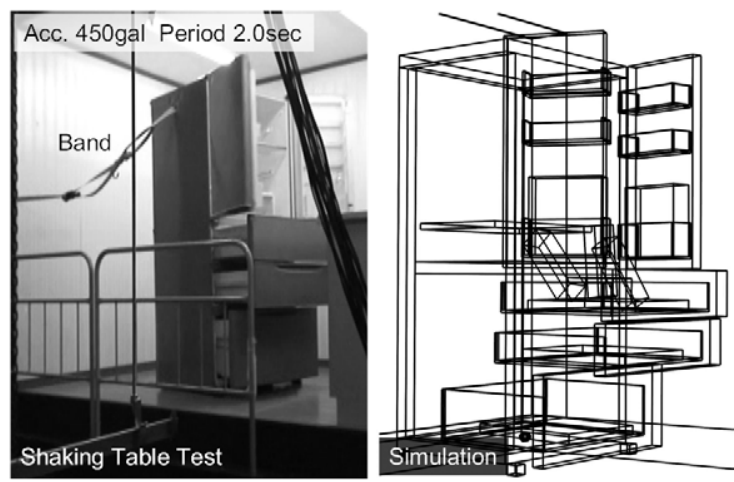

Fig.6 Figures after restriction of moving range by band

Table4 Simulation result of free shaking case

\begin{tabular}{|c|c|c|c|c|c|c|c|}
\hline \multicolumn{2}{|c|}{ Shaking Case } & \multicolumn{3}{|c|}{ Shaking Table Test } & \multicolumn{3}{|c|}{ Simulation } \\
\hline \begin{tabular}{|c|} 
Acc. \\
$\left(\mathrm{cm} / \mathrm{s}^{2}\right)$
\end{tabular} & $\begin{array}{c}\text { Period } \\
\text { (s) }\end{array}$ & $\begin{array}{c}\text { Restrained } \\
\text { by Band }\end{array}$ & $\begin{array}{c}\text { Door } \\
\text { Opening }\end{array}$ & $\begin{array}{c}\text { Drawer } \\
\text { Opening }\end{array}$ & $\begin{array}{c}\text { Restrained } \\
\text { byBand }\end{array}$ & $\begin{array}{c}\text { Door } \\
\text { Opening }\end{array}$ & $\begin{array}{l}\text { Drawer } \\
\text { Opening }\end{array}$ \\
\hline 250 & 2.0 & $x$ & - & - & $\bar{x}$ & - & - \\
\hline 250 & 2.5 & $x$ & - & - & $x$ & - & - \\
\hline 250 & 3.0 & $\mathrm{O}$ & - & $=$ & $X$ & - & $=$ \\
\hline 300 & 2.0 & $\mathrm{X}$ & - & - & $\mathrm{X}$ & - & - \\
\hline 300 & 2.5 & 0 & 0 & - & 0 & 0 & 0 \\
\hline 300 & 3.0 & 0 & 0 & - & 0 & 0 & 0 \\
\hline 350 & 2.0 & 0 & 0 & 0 & 0 & 0 & 0 \\
\hline 350 & 2.5 & 0 & 0 & 0 & 0 & 0 & 0 \\
\hline 400 & 2.0 & $\mathrm{O}$ & 0 & 0 & 0 & 0 & 0 \\
\hline 450 & 2.0 & 0 & 0 & 0 & $\mathrm{O}$ & 0 & 0 \\
\hline
\end{tabular}

:Doors or Drawers Open -: Not Open

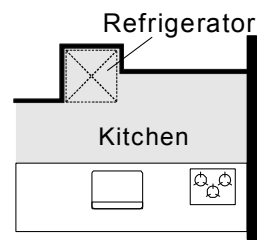

Fig.7 Common kitchen plan of high-rise residential building

答波，(2)内容物の量・質量配分の 2 種類を想定した。これらの因子 の組み合わせに対してシミュレーションを実施する。ここからは， (1), (2)の因子に対して設定した数值実験の計算条件について述べる。 


\section{(1) 床応答波}

床応答波として 1 方向（冷蔵庫の前後方向）の正弦波を用いた。 超高層住宅上階における長周期地震動を想定し, 正弦波の加振周期 として 1〜4 秒の 4 種類, 加振速度として $20 \sim 300 \mathrm{~cm} / \mathrm{s}$ の 11 種類 を想定した。最初の 2 周期分を加速時間とし, 継続時間は加振周期 の 8 倍とした。ただし, 継続時間が 20 秒間よりも短くなる場合は 20 秒間とした。振動実験を行って計算モデルの検証がなされている のは周期 $2 \sim 4$ 秒であるが, 参考のために, 周期 $1 \sim 2$ 秒も検討対象 に加えた。また，波の位相を反転したケースについても検討対象と した。以上の組み合わせを考慮すると, 全加振波の数は 88 波とな る。なお, 冷蔵庫の扉や引出しが開く方向やキャスターが転がる方 向が前後方向であること, 冷蔵庫は壁や食器棚等の家具と隣り合わ せに設置されていることが多く, 前後方向の挙動の方が主体的であ ることから, 冷蔵庫特有の複雑な地震時挙動が現れる前後方向のみ を検討対象とした。

(2) 内容物の量・質量配分

数值実験で用いた内容物の配置を Fig. 8 に示す。内容物を, 扉・ 引出し・本体上部の 3 種類にわけて配置した。扉の内容物は, 各扉 のポケットに計 4 つ配置した。引出しの内容物としては, 各引出し に一つずつ, 計 3 つを配置した。本体上部の内容物は, 3 段の棚に それぞれ 6 個ずつ, 計 18 個配置した。数值実験の際には, これら の内容物の配置や形状は変更せず，これらの総質量と質量配分を複 数パターン想定した。

まず, 内容物の全体量に対して i）最大, ii）中間, iii)空の 3 ケー スを想定した。冷蔵庫メーカーのカタログによると, 内容物の量を 最大でも定格容量の 60 〜 $70 \%$ 以内とすることが推奨されているこ とから, 定格容量の $70 \%$ をi最大ケースとし, その半分弱の $30 \%$ を ii)中間ケースとした。冷蔵庫の簡単な実態調査から得られた単位容 量あたりの内容物の質量(かさ比重)約 $0.2 \mathrm{~kg} / \mathrm{L}$ を用いて, i) 最大ケー スでは内容物の全質量を $480 \mathrm{~L} \times 0.2 \mathrm{~kg} / \mathrm{L} \times 0.7 \fallingdotseq 70 \mathrm{~kg}$ とし, ii) 中間 ケースでは $30 \mathrm{~kg}$ とした。

これを基本として，a）内容物全体の質量，b）内容物全体に対する 扉の内容物の割合, c) 扉の内容物以外の内容物の内で本体上部のも のの割合，にバラツキを与えた。a)全体の質量については，基本の 值および $10 \mathrm{~kg}$ の 3 ケースを設定した。b)内容物全体に対する扉の 内容物の割合および c) 扉の内容物以外の内容物の内で本体上部のも のの割合については，冷蔵庫の簡易な実態調查を元に，それぞれ $30 \% ・ 20 \%$ の 2 ケースおよび $20 \% ・ 40 \% ・ 60 \%$ の 3 ケースを想定し た。したがって, 内容物が i）最大およびii）中間の場合，それぞれ 18 ケースの計算を行った。

\section{2 検討結果}

Fig.9 に, 内容物の量が i)最大のケースにおける冷蔵庫の挙動の 一例を示す。加振周期が 3 秒, 加振速度が $300 \mathrm{~cm} / \mathrm{s}$ であり, a) 内 容物全体の質量が $70 \mathrm{~kg}, \mathrm{~b}$ ) 内容物全体に対する扉の内容物の割合が $20 \%$ ，c）扉の内容物以外の内容物の内で本体上部のものの割合が 40\%のケースである。摇れが始まって 3 秒前後で扉や引出しが開き 始め, 10 秒前後で, 傾きながら前面の壁に衝突した。その後は, 内 容物の散乱を伴いながら何度も激しく前後の壁に衝突し続けた。最 終的には, 本体上部の内容物の大半が下の引き出しの中に落下, あ るいは，床に散乱する状態となった。このような状況下のキッチン

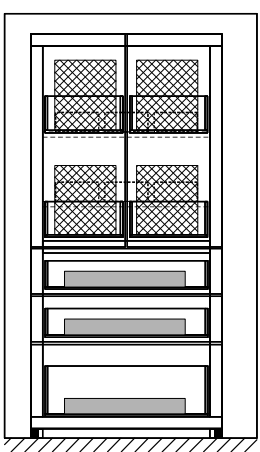

Front View

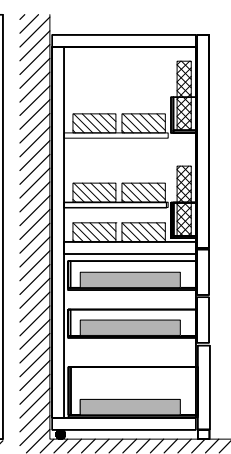

Side View

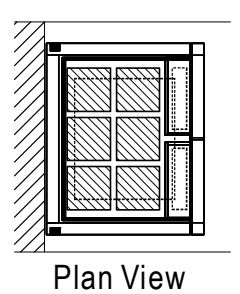

Contents

in Doors

$\square$ in Drawers

MIV in Upside of Body
Fig.8 Contents layout for parameter study

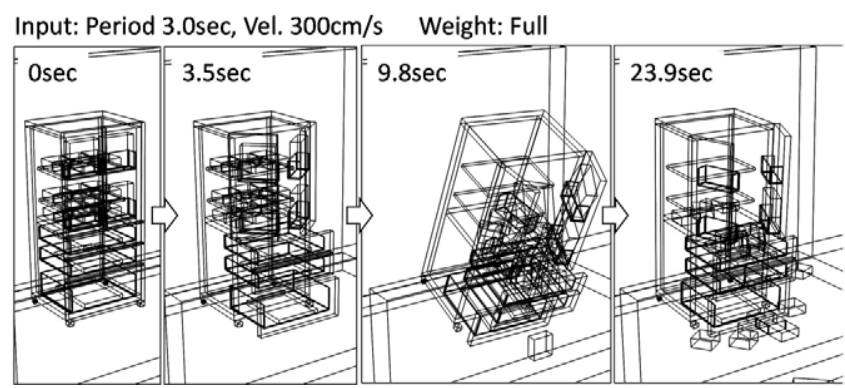

Fig.9 Snapshot of simulation
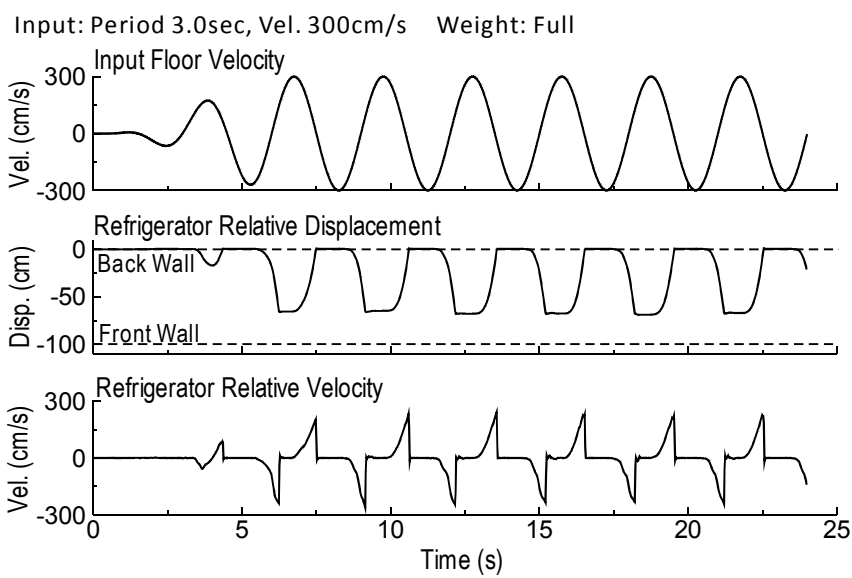

Fig.10 Time history of input floor velocity, relative displacement, and velocity of refrigerator

に人がいた場合，怪我をする恐れがあり，避難することも困難であ ることが推察される。

Fig.10 には, Fig.9 で示したケースにおける加振の速度波形，お よび, 冷蔵庫の床に対する相対速度と相対変位の時刻歷波形を示す。 相対変位については, 冷蔵庫の背面から前面に向かう方向が負の值 となっている。冷蔵庫の最大移動速度は, 本体の重心の床に対する 相対移動速度から求めた。このケースでは, 冷蔵庫が前面の壁に衝 突する際に扉や引出しが開いていたため, 移動量の最大值が $70 \mathrm{~cm}$ 程度となっている。相対速度については，負の值の鋭いピークが発 生している時に前面の壁との衝突が発生しており，正の值のピーク が発生している時間は背面の壁と衝突している。図を見ると, 前後 の壁との衝突が繰り返し発生しており, 最大で $250 \mathrm{~cm} / \mathrm{s}$ 程度で冷蔵 庫が動いていることが分かる。 


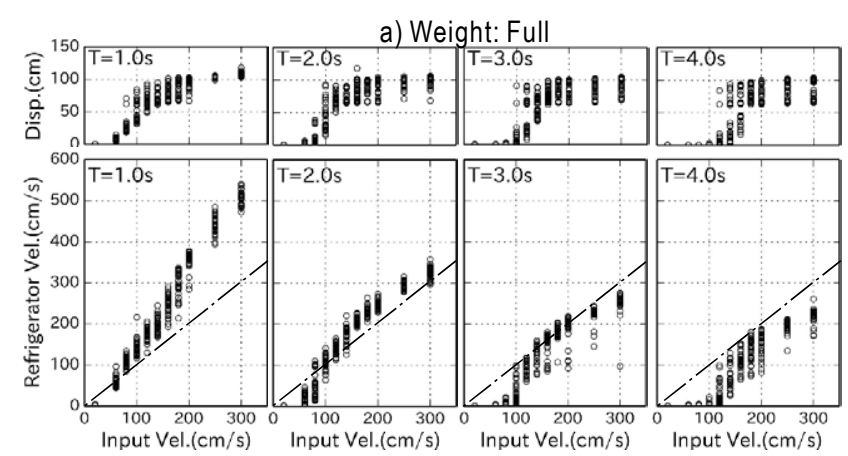

b) Weight: Medium

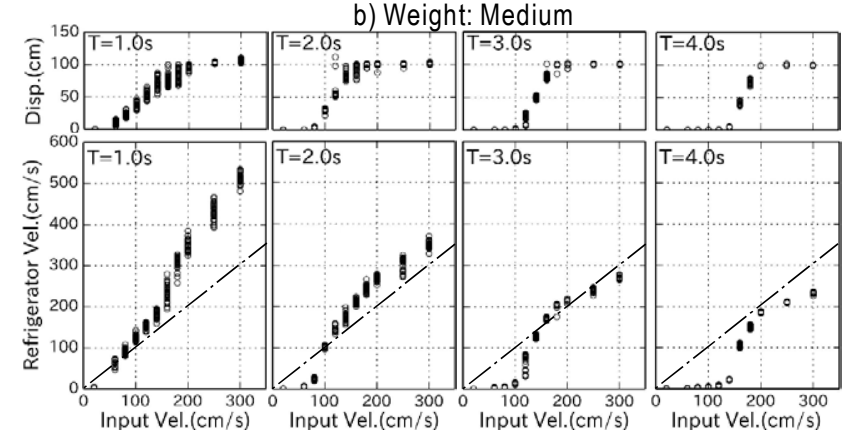

c) Weight: Empty

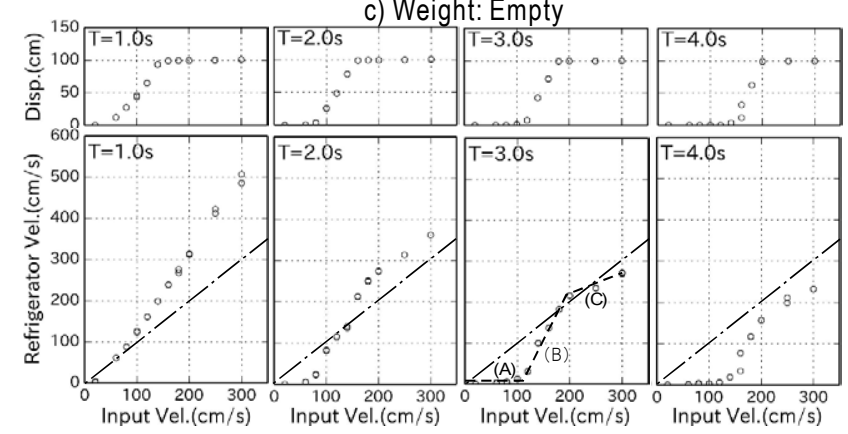

Fig.11 Input velocity vs refrigerator velocity and displacement

Fig. 11 に, 加振速度と冷蔵庫の変位や速度との関係を示す。内容 物の量で 3 段のブロック（上から内容物の量が a ）最大・b)中間・ c)空）に分けて表示しており, 各ブロック内の上段には加振速度と 冷蔵庫の最大相対変位の関係, 下段には加振速度と冷蔵庫の最大相 対速度の関係が示してある。また, 左から加振周期 1 秒, 2 秒, 3 秒, 4 秒の結果となっている。図中の 1 点鎖線は加振速度と冷蔵庫 の移動速度が同じとなる線を示している。

まず, 内容物が c)空のケースの冷蔵庫の移動速度に着目すると, 周期 2 秒以上では, 図中の破線に示寸ような 3 折れ線の関係が見て 取れる。3 折れ線の $(\mathrm{A})$ の部分では, 加振加速度が小さく, 冷蔵庫が ほとんど滑っていないので移動速度がほぼ 0 になっている。(B)の部 分では冷蔵庫が滑っており, 加振速度の増加に伴って移動速度も移 動量も大きくなっている。加振周期 3 秒の場合, (A) と (B)の境界が ある加振速度 $120 \mathrm{~cm} / \mathrm{s}$ は加振加速度 $250 \mathrm{~cm} / \mathrm{s}^{2}$ 程度に対応し, 設定 した摩擦係数と整合した結果になっている。さらに, (C)の部分では 壁と衝突して動きが制限され, 冷蔵庫の移動速度の増分が小さくな る傾向が見られる。この傾向は, 加振周期が長くなる程顕著にみら れ, 周期 3 秒以上では冷蔵庫の移動速度は加振速度と同じかそれ以 下となっている。

一方, 加振周期 1 秒では傾向が異なり, 加振速度と冷蔵庫の移動
速度はほぼ比例の関係になっており, 前述の(B)の部分のみが見られ る。(A) と(B)の境界が見られない理由については, 周期 1 秒では, 冷蔵庫が移動を始める加振加速度に対応する加振速度が小さい（約 $40 \mathrm{~cm} / \mathrm{s})$ ことが挙げられる。(B)と(C)の境界が見られない理由とし ては, 加振速度が $300 \mathrm{~cm} / \mathrm{s}$ のケースでも周期 1 秒だと加振変位が $50 \mathrm{~cm}$ 弱であるため, 冷蔵庫の移動速度が最大になる前に壁に衝突 して制限を受けることがほとんどないことが挙げられる。この結果, 周期 1 秒では, 加振速度が $100 \mathrm{~cm} / \mathrm{s}$ より大きい場合, 冷蔵庫の移動 速度が加振速度の 1.5 倍前後となっている。

内容物がある a)最大・b)中間の場合については, (A)と (B), およ び，(B) と（C)の境界が周期 2 秒〜 4 秒に見られ，周期 1 秒では境界 が見られないという傾向は同様である。冷蔵庫の移動速度や移動量 については, 内容物が a)最大のケースの周期 3〜4 秒を除いては, 多少のばらつきは見られるものの，c)空の場合と平均的にはほぼ同 じ值となった。内容物が a)最大のケースの周期 $3 \sim 4$ 秒については, 移動速度や移動量の最大值は c) 空の場合とほぼ同じであるが, 值が 小さくなるケースが多いことが分かる。移動速度や移動量が小さく なっているケースでは, 床応答の振幅が大きくなる前に, 本体が傾 いて前面の壁にもたれかかり，それ以降動かなくなっていた。この ような挙動になるのは, 内容物の量が多くなると, 扉や引出しにか かる慣性力が大きくなって開きやすくなり, 開いた際の重心のずれ が大きくなるので倒れやすくなるためである。内容物が c) 空の場合 は扉や引出しはほとんどのケースで開かず，内容物が a)最大のケー スでは加振加速度が $150 \mathrm{~cm} / \mathrm{s}^{2}$ 程度, b)中間のケースでは $200 \mathrm{~cm} / \mathrm{s}^{2}$ 程度で，それぞれ扉や引出しが開き始めた。また，内容物の質量配 分が異なる場合でも, 挙動に大きな変化は見られず全体的な傾向は 変わらなかった。

ここで, 物が壁に衝突した際の衝撃力 $(\mathrm{N})$ は, [質量 $] \times[$ 衝突速度 $(\mathrm{m} / \mathrm{s})]_{2} /(2.0 \times[$ 移動量 $(\mathrm{m})])$ の式により求められるが, 冷蔵庫が人に 衝突した際の負傷の可能性を冷蔵庫の移動速度から確認してみる。

[移動量]を物が衝突した際の変形量とみなし, 内容物が $70 \mathrm{~kg}$ (総質 量 $172.6 \mathrm{~kg}$ ), 冷蔵庫の衝突速度を $200 \mathrm{~cm} / \mathrm{s}$, 冷蔵庫が人に衝突した 際の胸部の変形量を $5 \mathrm{~cm}$ と仮定すると, 衝撃力は約 $7000 \mathrm{~N}$ となる。 本棚がベッドに寝ている人に覆いかぶさった場合の静的な荷重は $400 \mathrm{~N} \sim 1000 \mathrm{~N}$ で，幼児や児童が死亡する危険性があると言われて

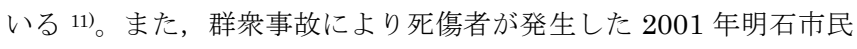
夏まつりでは，一人につき約 $2000 \mathrm{~N}$ の力が作用していたと推定さ れている ${ }^{12)}$ 。これらの值と単純な比較は出来ないが，冷蔵庫の衝撃 力は十分に大きく, 冷蔵庫が人に衝突すると負傷する可能性が高い と考えられる。そのため, 冷蔵庫は壁にしっかりと固定して動かな いようにしておくことが重要だと考えられる。

\section{5. 結論}

本研究では, 長周期地震動に対して, 扉や引出しの開閉や内容物 を考慮した泠蔵庫の地震時挙動について, 振動実験と数值シミュレ ーションを用いて検討を行った。まず，冷蔵庫単体の振動実験を実 施し, 地震時の基本的な挙動を把握した。続いて, 計算モデルを構 築し, 概ね振動実験の挙動をシミュレーションで再現できることを 確認した。そして, その計算モデルに基づいて, 条件を変えた数多 くのケースに対して数值実験を行い, 扉や引出しの開閉の有無や内 
容物の量が冷蔵庫の地震時挙動に与える影響について検討すると共 に, 長周期地震動によるキッチンでの室内被害について考察を行っ た。

その結果, 内容物がある場合は $150 \mathrm{~cm} / \mathrm{s}^{2}$ 程度で扉や引出しが開き 始め, $250 \mathrm{~cm} / \mathrm{s}^{2}$ 程度で滑り出すことが分かった。また, 加振周期 3 秒以上の長周期では, 冷蔵庫の移動速度は最大でも加振速度と同程 度となることが分かった。そして, 冷蔵庫は, 地震時に扉や引出し の開閉と内容物の散乱を伴いながら, 前後の壁と激しく衝突を繰り 返し, このような状況下のキッチンに人がいた場合, 負傷する可能 性が高く，避難することが困難であることが推察された。

本論文では, 超高層住宅における地震時の室内被害に関して冷蔵 庫単体の挙動に着目して検討を実施したが，今後は，冷蔵庫を含め た住宅全体の室内被害について検討していく予定である。

\section{参考文献}

1）榎田竜太・長江拓也・梶原浩一・紀 暁東 - 中島正愛 : 大振幅応答を実 現する震動台実験手法の構築と超高層建物の室内安全性, 日本建築学会構 造系論文集，第 74 巻，第 637 号, pp. 467-474, 2009. 3.

2) 東京消防庁: 平成 23 年 (2011 年) 東北地方太平洋沖地震調查報告書, 2012.

3）東京都防災ホームページ : 家具・家電転倒防止対策, http://www. bousai. metro. tokyo. jp/bousai/1000027/1000289. html, 参照 2014. 10.27.

4) 金子美香・林康裕: 剛体の転倒率曲線の提案, 日本建築学会構造系論文集, 第 536 号, pp. 55-62，2000. 10.

5）田村和夫 - 金子美香 : 室内家具の固定対策の検討, 長周期地震動対策に 関する公開研究集会, 日本建築学会・構造委員会・高機能社会耐震工学口 ーキンググループ, pp. 227-265, 2008. 3.

6) 金子美香: 東日本大震災の家具類の被害状況々簡易被害推定結果との比 較, 長周期地震動対策に関する公開研究集会, 日本建築学会 - 構造委員 会・長周期建物地震対応小委員会, 2012.3.

7) 桜井和敏, 北沢千弘, 斉藤洋, 吉田靖: 室内内容物（冷蔵庫, 衣類乾燥 機）の振動実験について, 昭和 58 年消防科学研究所報 20 号, 1983.

8）長谷川晶一・他: Springhead2, http://springhead. info/wiki/index. php, 参照 2014. 10. 27.

9）金子美香：地震時における家具の転倒率推定方法, 日本建築学会構造系 論文集，第 551 号，pp. 61-68，2002.1.

10）大町達夫, 荒井靖博: 個別要素法で用いる要素定数の決め方について, 構造工学論文集, Vol.32A, pp. 715-723，1986.3.

11）中泉洋香, 高橋徹, 斎藤大樹：巨大地震に対する超高層集合住宅の 人・生活を守る技術の開発，その 4 家具の転倒による胸部損傷可能性に関 寸る考察, 日本建築学会大会学術講演梗概集, B-2, 構造 II, pp. 951-952, 2011. 8 .

12）宮野道雄, 生田英輔, 長嶋文雄, 田中裕, 梶原浩一, 奥野倫子：地震時 の人体被災度計測手法の開発：胸部圧迫実験用ダミ一の作製, 地域安全 学会論文集 $(10), 2008.11$. 


\title{
EVALUATION OF INDOOR DAMAGE IN HIGH-RISE BUILDINGS \\ DUE TO LONG PERIOD GROUND MOTION
}

- Seismic behavior of refrigerator considering opening doors and drawers -

\author{
Toshiyuki MASATSUKI*, Saburoh MIDORIKAWA** , Hiroyuki MIURA*** \\ and Tetsuro HATSUOKA**** \\ * Structure Engineering Dept., Kozo Keikaku Engineering Inc. \\ ** Prof., Dept. of Built Environment, Tokyo Institute of Technology, Dr. Eng. \\ ** Assoc. Prof., Hiroshima Univ., Dr. Eng. \\ **** Kajima Corporation (Former Graduate Student, Tokyo Institute of Technology)
}

The aim of this study is to evaluate indoor damage in high-rise residential buildings due to long period ground motion. Enokida et al. (2009) indicates the risk that overturning furniture, such as a cupboard or a refrigerator, would hurt people in a kitchen, so it is important to evaluate the seismic behavior of such furniture. The seismic behavior of simple furniture, such as a cupboard, can be estimated using the previous method, but the seismic behavior of a refrigerator is complex and it is difficult to evaluate it because its doors and drawers would open during floor shaking. In this study the seismic behavior of a refrigerator was evaluated considering opening doors and drawers using shaking table tests and a simulation. First, the shaking table test of a refrigerator was conducted in order to understand the basic characteristics of the seismic behavior of a refrigerator. And the second, the calculation model of the refrigerator was built that can simulate the realistic behavior of the shaking table test. Finally, many cases of simulations were carried out to evaluate the effects of doors and drawers opening or the amount and weight balance of contents in the refrigerator. As the result of this study, the doors and drawers begins to open about $150 \mathrm{~cm} / \mathrm{s}^{2}$ in case that contents exist, and the refrigerator begins to move about $250 \mathrm{~cm} / \mathrm{s}^{2}$. The moving velocity of the refrigerator is equal to or lower than shaking velocity because the moving velocity is limited by a collision against wall in case that shaking period is $3.0 \mathrm{sec}$ or over. And the refrigerator would collide many times against walls severely with scattering its contents during floor shaking. So it is highly possible that it injures people and blocks evacuation routes. 